\title{
Stability of Angiotensin I-converting Enzyme Inhibitory Activity of Peptides Extracted from Dry-cured Jinhua Ham
}

\author{
Qing-xiang Zuo, Wan-gang Zhang, Lu-juan Xing, Jin-xiao Zheng, Guang-hong Zhou* \\ Key Laboratory of Meat Processing and Quality Control, Ministry of Education, College of Food Science and Technology, \\ Jiangsu Collaborative Innovation Center of Meat Production and Processing, Quality and Safety Control, \\ Nanjing Agricultural University, Nanjing 210095, China \\ *Corresponding author: guanghong.zhou@hotmail.com
}

\begin{abstract}
Angiotensin I-converting enzyme (ACE) inhibitory activity of peptides extracted from traditional dry-cured Jinhua ham was investigated. The ACE-inhibitory activity was measured after the treatments of heat, $\mathrm{NaCl}, \mathrm{pH}$ and simulated gastro-intestinal digestion. Peptides possessed an ACE-inhibitory activity of $53.53 \%$ at 10 $\mathrm{mg} / \mathrm{mL}$ and showed a good stability against different heating temperatures (up to $100^{\circ} \mathrm{C}$ ), heating times (up to $60 \mathrm{~min}$ ) and acid conditions. The $\mathrm{NaCl}$ had no significant effects on the ACE-inhibitory activity, while there was a sharp decline under alkaline condition. The ACE-inhibitory activity increased by $4.01 \%$ after pepsin treatment and then remained constant after trypsin treatment. The increased ACE-inhibitory activity after pepsin digestion could be explained by the greater exposure of hydrophobic residues. In this study, peptides extracted from Jinhua ham were proved to have ACE-inhibitory activity which showed a good stability against various processing conditions as well as the simulated gastro-intestinal digestion.
\end{abstract}

Keywords: Jinhua ham, ACE-inhibitory peptides, stability, processing conditions, gastro-intestinal digestion

Cite This Article: Qing-xiang Zuo, Wan-gang Zhang, Lu-juan Xing, Jin-xiao Zheng, and Guang-hong Zhou, "Stability of Angiotensin I-converting Enzyme Inhibitory Activity of Peptides Extracted from Dry-cured Jinhua Ham." Journal of Food and Nutrition Research, vol. 5, no. 5 (2017): 301-308. doi: 10.12691/jfnr-5-5-3.

\section{Introduction}

A number of peptides generated from food proteins have been shown to possess various bioactivities such as antihypertensive, antioxidant, immunomodulation, antimicrobial and antiobesity $[1,2,3]$. Bioactive peptides can be released by hydrolysis, digestion or during food processing including fermentation and ripening [4,5]. Typically, bioactive peptides are small molecular peptides with the lengths ranging from 2 to 30 amino acids. Because of small size, these peptides are able to pass the digestive epithelial barrier into capillary blood vessels where they are then transported to specific locations and perform their biological functions [6].

Jinhua ham is a famous dry-cured meat product in China and the process of fermentation usually takes 8 to 10 months in average. Dry-cured meat product can release a great quantity of free amino acids and small peptides during fermentation and ripening periods [7]. During the long-ripening period, muscle proteins are hydrolyzed by endogenous enzymes, slowly releasing small peptides and free amino acids which contribute to the unique flavor of Jinhua ham $[8,9]$. In terms of bioactive peptides in Jinhua ham, current studies have focused on their antioxidant activity. Crude peptides extracted from Jinhua ham were proved to possess DPPH scavenging ability of $77.39 \%$ and great antioxidant activity in PC12 cell model $[10,11]$. Peptide with sequence of GKPNV purified from Jinhua ham has been isolated and assayed to have a great antioxidant activity [12]. However, no studies have investigated the antihypertensive abilities of Jinhua ham peptides (JHP) to date.

Angiotensin I-converting enzyme (ACE) is a dipeptidylcarboxypeptidase which plays an important physiological role in regulating blood pressure [13]. This enzyme converts inactive angiotensin I to angiotensin II, a potent vasopressor, and concomitantly, inactivates the vasodilating compound bradykinin. Therefore, substances with ACE-inhibitory activity possess antihypertensive effects by reducing the systolic blood pressure [14]. Since ACE-inhibitory peptides were first isolated from serpent venom [15], many studies have been directed to research on antihypertensive peptides generated from food proteins [2]. In recent studies, peptides with ACE-inhibitory activity such as KAPVA and PTPVP were obtained from pork after a simulated gastrointestinal digestion [16]. Moreover, peptides extracted from Spanish dry-cured ham have been proved to possess both in vitro ACE-inhibitory activity and in vivo antihypertensive activity [17]. However, to our knowledge, no research has focused on the ACE-inhibitory activity of peptides in Chinese dry-cured ham. Moreover, the research on the peptides with ACE-inhibitory activity has mainly been aimed at their separation and characterization. There is little 
information available regarding the stability of the ACE-inhibitory activity under food processing and digestion conditions. In the current study, the ACE-inhibitory activity of peptides extracted from Jinhua ham was initially investigated and then the effect of processing, including heat, $\mathrm{NaCl}$ content, $\mathrm{pH}$ as well as simulated gastro-intestinal digestion was measured to evaluate the stability of ACE-inhibitory peptides.

\section{Materials and Methods}

\subsection{Materials}

Jinhua dry-cured hams were purchased from Jinzi Company (Jinhua, Zhejiang, China). Angiotensin-converting enzyme (from rabbit lung, $2 \mathrm{U} / \mathrm{mg}$ protein), a substrate peptide (Hip-His-Leu), pepsin (3000-3500 U/mg protein) and trypsin (285 U/mg protein) were obtained from Sigma Aldrich (St. Louis, MO, USA). All other reagents were of analytical grade and purchased from Shoude Chemical Reagent Company (Nanjing, China).

\subsection{Jinhua Dry-cured Ham Preparation}

Jinhua hams were processed using traditional methods involving six main steps: cooling, salting, soaking and washing, drying, ripening and post-ripening. Six hams were randomly selected as samples and then denuded of fat and connective tissues. The biceps femoris muscle was fully cut from each ham, packed and stored at $-20^{\circ} \mathrm{C}$ before used.

\subsection{Peptides Extraction and Desalting Procedures}

The extraction was performed according to Xing, $\mathrm{Hu}$ [18] with some modifications. The muscle (25 g) was minced and then homogenized in $100 \mathrm{~mL}$ of phosphate buffer at ambient temperature $(0.2 \mathrm{mmol} / \mathrm{L}, \mathrm{pH} 7.2)$ using a homogenizer (T25 Digital Ultra-Turrax, IKA, Germany) for three 10 -s periods at $18,000 \mathrm{rpm}$. The homogenate was centrifuged at $12,000 \mathrm{~g}$ for $20 \mathrm{~min}$ at $4^{\circ} \mathrm{C}$. After filtering through filter paper, the supernatant was de-proteinized by adding 2.5 volumes of ethanol. The mixture was maintained for $6 \mathrm{~h}$ at $4^{\circ} \mathrm{C}$ and then again centrifuged at $12,000 \mathrm{~g}$ for $20 \mathrm{~min}$ at $4^{\circ} \mathrm{C}$. The resulting supernatant was freeze-dried. Peptides were desalted by solid phase extraction using an Oasis HLB extraction cartridge $(20 \mathrm{cc}$, Waters, Ireland), lyophilized and stored at $-20^{\circ} \mathrm{C}$ until being used.

\subsection{Peptide Content}

The peptide content of Jinhua ham was measured using the method of Church, Swaisgood [19] with slight modifications. The o-phthaldialdehyde (OPA) solution was prepared daily, made by combining the following reagents and adjusted to $100 \mathrm{~mL}$ by the addition of distilled water: $80 \mathrm{mg}$ of OPA (dissolved in $2 \mathrm{~mL}$ of methanol); $50 \mathrm{~mL}$ of sodium tetra-borate $(0.1 \mathrm{~mol} / \mathrm{L})$; $200 \mu \mathrm{L}$ of $\beta$-mercaptoethanol; and $5 \mathrm{~mL}$ of $20 \%(\mathrm{w} / \mathrm{w})$ sodium dodecyl sulfonate. The $200 \mu \mathrm{L}$ extract solution
( $1 \mathrm{mg} / \mathrm{mL}$ of concentration in deionized water) was added into $4 \mathrm{~mL}$ of OPA solution and then mixed by inversion. The mixture was incubated for $2 \mathrm{~min}$ in the dark at ambient temperature, and the absorbance at $340 \mathrm{~nm}$ was measured using a fluorescence spectrophotometer (SpectraMax M2, Molecular Devices Limited, USA). Casein was chosen for the standard substance, which was detected over a linear concentration range. The peptide content of samples was calculated using a standard curve for casein.

\subsection{Assay of ACE-inhibitory Activity}

The assay method of ACE-inhibitory activity was modified from that of Cushman and Cheung (1971) [20]. Each sample solution $(40 \mu \mathrm{L})$ was added into $100 \mu \mathrm{L}$ of borate buffer ( $\mathrm{pH}$ 8.3) containing $0.3 \mathrm{M} \mathrm{NaCl}$, and $6.5 \mathrm{mM}$ Hip-His-Leu (HHL). Twenty $\mu \mathrm{L}$ ACE $(0.1 \mathrm{U} / \mathrm{mL})$ solutions were then added to each sample and the reaction mixture was incubated at $37^{\circ} \mathrm{C}$ for $45 \mathrm{~min}$. The reaction was stopped by the addition of $200 \mu \mathrm{L}$ of $\mathrm{HCl}(1 \mathrm{~mol} / \mathrm{L})$ and $1.5 \mathrm{~mL}$ of ethyl acetate was added for the extraction of hippuric acid. Following centrifugation (1,200 $\mathrm{g}$ for $10 \mathrm{~min}$ ), $1 \mathrm{ml}$ of supernatant was transferred into a test tube and the elimination of ethyl acetate was achieved by heat evaporation $\left(60^{\circ} \mathrm{C}\right.$ for $\left.120 \mathrm{~min}\right)$. The hippuric acid was dissolved in distilled water $(2 \mathrm{~mL})$ and the absorbance was determined at $228 \mathrm{~nm}$ using a spectrophotometer (SpectraMax M2, Molecular Devices Limited, USA). The ACE inhibition activity (\%) was shown as equation (1), where $\mathrm{Aa}$ is the absorbance when the sample is replaced by borate buffer; $\mathrm{Ab}$ is the absorbance when ACE and the sample are replaced by borate buffer; and $\mathrm{A}$ is the absorbance of HHL, ACE and the sample. Experiments were carried out in triplicate for each sample.

$$
\begin{aligned}
& \text { ACE inhibitory activity } \\
& =\left[\left(A_{a}-A\right) /\left(A_{a}-A_{b}\right)\right] \times 100 \% .
\end{aligned}
$$

\subsection{Effect of Different Conditions on ACE-Inhibitory Activity of Jinhua Ham Peptides}

\subsubsection{Effect of Heat Treatment on ACE-inhibitory Activity of Peptides}

The peptides extracted from Jinhua ham were dissolved in borate buffer at a concentration of $5 \mathrm{mg} / \mathrm{mL}$. Solutions were submitted to different heat treatment conditions. Peptide solutions were either placed in a water bath for 10 $\min$ at $20,40,60,80$ or $100^{\circ} \mathrm{C}$, or the solutions were also treated at $100^{\circ} \mathrm{C}$ for $5,10,15,30$ or $60 \mathrm{~min}$. All solutions were cooled to $0^{\circ} \mathrm{C}$ in ice before the assay of ACE-inhibitory activity as described above.

\subsubsection{Effect of $\mathrm{NaCl}$ on ACE-inhibitory Activity of Peptides}

The peptide solutions were prepared with $2,4,6,8$ or $10 \%(\mathrm{w} / \mathrm{w}) \mathrm{NaCl}$, maintained in a water bath for $20 \mathrm{~min}$ at $100^{\circ} \mathrm{C}$ and then rapidly taken to $0^{\circ} \mathrm{C}$ in ice. To exclude the potential influence of $\mathrm{NaCl}$ on the measurement of ACE-inhibitory activity, samples were then desalted by solid phase extraction using an Oasis HLB extraction 
cartridge (20 cc, Waters, Ireland) and lyophilized for the assay of ACE inhibitory activity.

\subsubsection{Effect of pH on ACE-inhibitory Activity of Peptides}

The $\mathrm{pH}$ of peptides solutions was adjusted to 3.0, 5.0, 7.0, 9.0 and 11.0 with $1 \mathrm{M} \mathrm{H}_{3} \mathrm{PO}_{4}$ or $1 \mathrm{M} \mathrm{NaOH}$ and then maintained at $20^{\circ} \mathrm{C}$ for $1 \mathrm{~h}$. The $\mathrm{pH}$ was then adjusted to 7.0 before the assay of ACE-inhibitory activity.

\subsubsection{Effect of in Vitro Digestion on ACE-inhibitory Activity of Peptides}

A pepsin-trypsin in vitro digestion was carried out following the method of De, Deplancke [21]. To simulate the digestion in the stomach, the peptide samples were adjusted to $\mathrm{pH} 2.0$ with $1 \mathrm{M} \mathrm{HCl}$. Pepsin was then added at an enzyme to peptide ratio of $1: 250$. The reaction mixture was incubated at $37^{\circ} \mathrm{C}$ for $2 \mathrm{~h}$ with shaking and then the tubes were placed in boiling water for $10 \mathrm{~min}$ to terminate the treatment with pepsin. Subsequently, the samples were rapidly cooled in ice and centrifuged at $5,000 \mathrm{~g}$ for $15 \mathrm{~min}$. The supernatant was collected and divided into two portions. One was lyophilized and the other was submitted to the treatment with trypsin. To proceed with the trypsin digestion, the samples were first adjusted to $\mathrm{pH} 7.5$ with $1.0 \mathrm{M} \mathrm{NaOH}$. Trypsin was added in an enzyme to substrate ratio of $1: 250$, and the above procedure was repeated. The supernatant was then freeze-dried and stored at $-20^{\circ} \mathrm{C}$.

\subsection{Total and Free Amino Acids Analysis}

The total amino acids of peptides were determined using the method described by Bidlingmeyer, Cohen [22] with slight modifications. Each peptide sample was mixed with $6 \mathrm{M} \mathrm{HCl}$ and heated at $110^{\circ} \mathrm{C}$ for $24 \mathrm{~h}$ in an oven before derivatization with phenyl isothiocyanate. In order to determine tryptophan, alkaline hydrolysis was then carried out. Samples were filtered through a Millipore filter having a pore diameter of $0.45 \mu \mathrm{m}$ (Millipore, Bedford, MA). Each sample $(20 \mu \mathrm{L})$ was analyzed with amino acid analyzer Hitachi L-8900A (Hitachi Ltd., Japan).

Samples for free amino acid analysis were prepared following the procedures described by Juanmarcos, Purevdorj [23]. Free amino acids were then analyzed by repeating the above performance.

\subsection{Surface Hydrophobicity Measurement}

The surface hydrophobicity was determined using 1-anilinonaphthalene-8-sulphonic acid (ANS) as the fluorescence probe following by the method described by Haskard and Ecy [24]. Each sample was prepared to an appropriate concentration with $0.1 \mathrm{M}$ phosphate buffer (pH 7.0). Subsequently, $2 \mathrm{~mL}$ of sample, concentrations ranging from 0.3 to $1.5 \mathrm{mg} / \mathrm{mL}$, was added into $10 \mu \mathrm{L}$ of ANS solution (8mM ANS in 0.1 M phosphate buffer, $\mathrm{pH} 7.0$ ). The fluorescence intensity of each sample was measured using a fluorescence spectrophotometer (SpectraMax M2, Molecular Devices Limited, USA) at excitation and emission wavelengths of 374 and $485 \mathrm{~nm}$. The index of surface hydrophobicity was determined from the initial slope of the plot of fluorescence intensity versus protein concentration.

\subsection{Statistical Analysis}

Analyses on individual samples were repeated 6 times. All the data obtained was subjected to one-way analysis of variance (ANOVA). Significant differences were determined by Duncan's multiple-range test using SAS software. Data are expressed as means and standard errors and differences were considered significantly at $\mathrm{P}<0.05$.

\section{Results and Discussion}

\subsection{ACE-inhibitory Activity of JHP}

During the long-term processing of dry-cured Jinhua ham, an intense proteolysis occurs as a consequence of endogenous proteolytic enzymes, resulting in the generation of small peptides and amino acids [8,25]. Zhu, Zhang [12] reported that the peptide content of Jinhua hams was $1.16 \%$ and that these crude peptides also exhibited high antioxidant activity. In the study of Escudero, Mora [26], ACE-inhibitory activity of peptides from Spanish dry-cured ham was also investigated and an inhibition of $60.7 \%$ at $10 \mathrm{mg} / \mathrm{mL}$ was reported. In order to study the ACE-inhibitory effect of JHP, the ACE-inhibitory activity of the peptides was analyzed under a gradient range of concentrations (Figure 1). JHP were shown to have the ACE-inhibitory ability which was increased with the increasing concentration of peptides. The maximum ACE-inhibitory effect in our study was $53.53 \%$ at $10 \mathrm{mg} / \mathrm{mL}$.

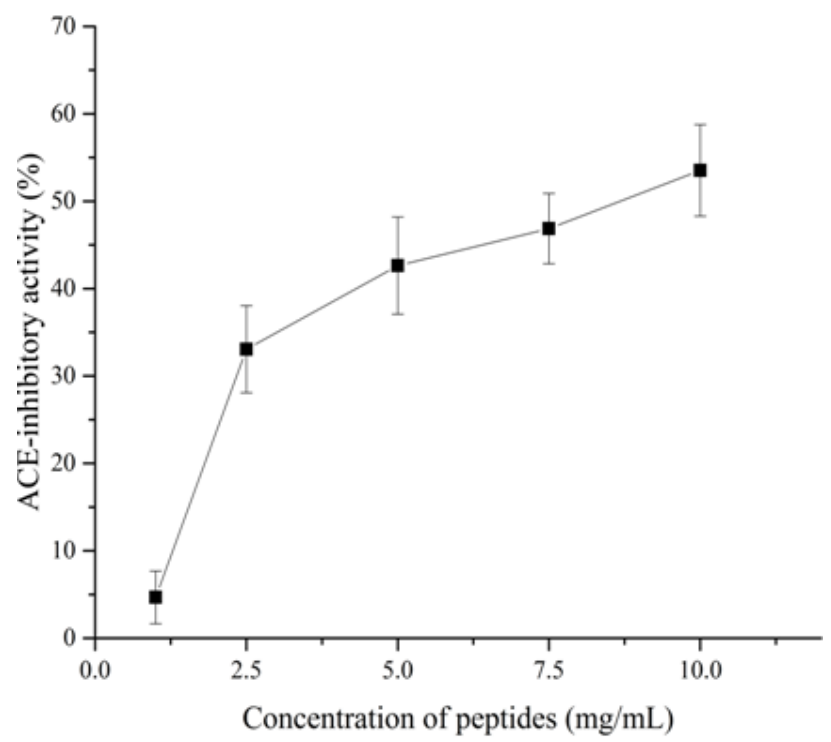

Figure 1. ACE-inhibitory activity of Jinhua ham peptides at different concentrations

\subsection{Effect of Processing on ACE-inhibitory Activity of JHP}

\subsubsection{Effect of Heat Treatment on ACE-inhibitory Activity of JHP}

Since heat treatment is often applied to hams, it was meaningful to determine the stability of ACE-inhibitory activity when subjected to various heat treatment conditions. The heating temperatures used in the first study (Figure $2 \mathrm{a}$ ) ranged from 30 to $100^{\circ} \mathrm{C}$ for a time of 
$10 \mathrm{~min}$; in the second, the heating times ranged from 5 to $60 \mathrm{~min}$ at $100^{\circ} \mathrm{C}$ (Figure 2b). There were no significant differences in ACE-inhibitory activity of JHP under the various conditions, indicating that the ACE-inhibitory activity of JHP had resistance to heat treatment. These results are consistent with the findings for the stability of peptides extracted from Spanish dry-cured ham at different temperatures $\left(50-117^{\circ} \mathrm{C}\right.$ for $\left.6 \mathrm{~min}\right)$ and at different heating time $\left(3-60 \mathrm{~min}\right.$ at $\left.117^{\circ} \mathrm{C}\right)$ [26]. Moreover, it has been also reported that the ACE-inhibitory peptides obtained from tuna cooking juice showed similar activities after heating at different temperatures $\left(20-100^{\circ} \mathrm{C}\right.$ for $\left.2 \mathrm{~h}\right)$ [27].
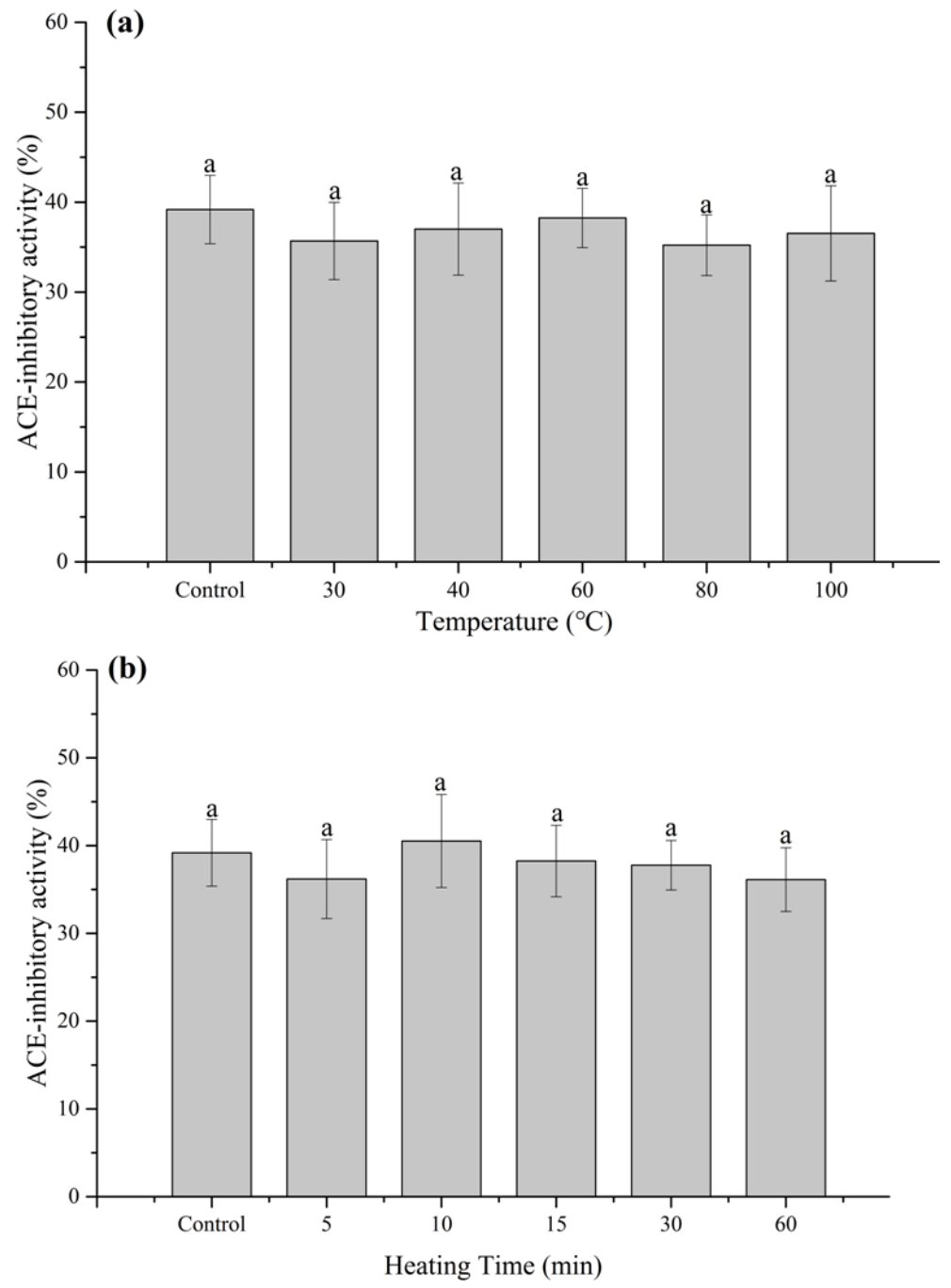

Figure 2. Stability of ACE-inhibitory activity of JHP after: (a) 10 min heating at various temperatures, and (b) $100{ }^{\circ} \mathrm{C}$ heating for various times. Bars with different letters are significantly different

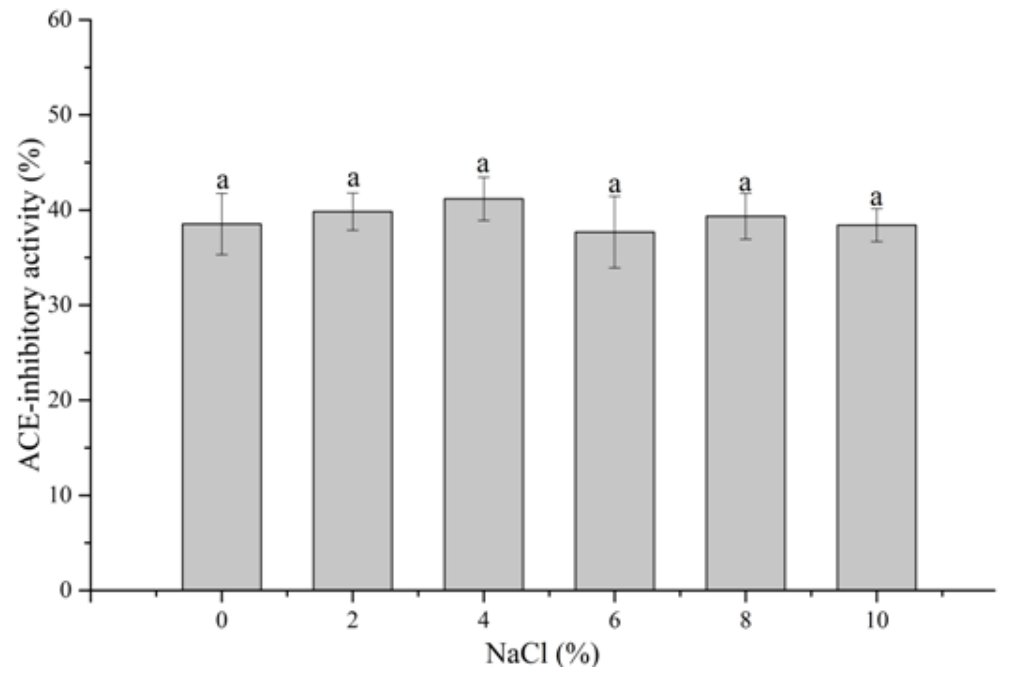

Figure 3. Changes in ACE-inhibitory activity of JHP at different $\mathrm{NaCl}$ percentages. Bars with different letters are significantly different 


\subsubsection{Effect of $\mathrm{NaCl}$ on ACE-inhibitory activity of JHP}

Basing on traditional Chinese eating habits, Jinhua dry-cured hams are often used for making soup, which may contain various concentrations of salt. It was, therefore, necessary to consider the effect of $\mathrm{NaCl}$ on the stability of these ACE-inhibitory activity of peptides. As shown in Figure 3, there were no significant changes in ACE-inhibitory activity of peptides with different $\mathrm{NaCl}$ contents. The results suggested that the addition of $\mathrm{NaCl}$ did not significantly affect the ACE-inhibitory activity of peptides.

\subsubsection{Effect of pH on ACE-inhibitory Activity of JHP}

Changes in ACE-inhibitory activity of the JHP were observed over the $\mathrm{pH}$ range of 3.0 to 11.0 (Figure 4). Compared with the inhibitory activity at $\mathrm{pH} \mathrm{7.0,} \mathrm{it} \mathrm{was}$ essentially stable under acid conditions but exhibited a significant decline when exposed to alkaline conditions at $\mathrm{pH} 9.0$ and 11.0. It is likely that de-amination and racemization reactions of peptides may be the main reasons for the instability of ACE-inhibitory activity. Higher $\mathrm{pH}$ values are favorable for the de-amination reaction, which could alter the structure and conformation of peptides leading to the loss of bioactivity [28,29]. Also, it has been reported that with alkaline treatment, the structure of protein isolates in the rice residue was greatly damaged due to the alkaline denaturation [30]. These studies confirm that alkaline conditions are unfavorable for the stability of ACE-inhibitory activity of JHP.

\subsection{Effect of in Vitro Digestion on Amino Acid Contents of JHP}

The initial total amino acid content and the free amino acid content of JHP are shown in Table 1, together with the free amino acid contents present after digestion with pepsin and then with trypsin. The amount of total amino acid content was $27.67 \mathrm{mg} / \mathrm{mL}$, in which free amino acids accounted for $32.19 \%$. After a $2 \mathrm{~h}$ of pepsin digestion, the proportion did not change significantly. However, the content of free amino acids increased by $5.16 \%$ at the end of simulated trypsin digestion. Regarding specific changes in the free amino acid contents, most were increased during two steps of digestion except for His, Met and Ser. These results suggest that although pepsin was capable of hydrolyzing peptides into smaller fragments, the liberation of free amino acids during digestion resulted mainly from trypsin activity. At the termination of the simulated in vitro digestion, the free amino acids accounted for $37.39 \%$ of original total amino acids. At this stage, more than $60 \%$ of the amino acids were present as peptides. It has been reported that some small molecular-sized peptides are directly absorbed through the intestine by a peptide transport system which plays an important role in the digestion and the absorption of protein [31].

Although the structure-activity relationship of ACE-inhibitory peptides is not well known, some of these peptides do share some common properties. The C-terminal sequences of these peptides appear to bind to ACE, acting as competitive inhibitors. It has been reported that some peptides with C-terminal proline, lysine and hydrophobic (aromatic and branched side chain) residues contribute to the ACE-inhibitory activity [32,33]. From Table 2, it can be calculated that, in addition to the free amino acids, Pro, Lys and the hydrophobic amino acids account for $47.35 \%$ of the total amino acids. This could be a proof for the presence of ACE-inhibitory activity of peptides extracted from Jinhua ham.

\subsection{Effect of in Vitro Digestion on Surface Hydrophobicity of JHP}

Changes in the surface hydrophobicity of JHP, following pepsin-trypsin simulated digestion are shown in Figure 5. The surface hydrophobicity of the sample was increased after the treatment with pepsin but decreased when further digested with trypsin. There are a number of factors that could account for the exposure of hydrophobic groups, such as heat treatment, protein oxidation and hydroxylation [34]. In our study, pepsin may have split the peptides into small chains, thus exposing more hydrophobic residues, whereas trypsin hydrolyses the peptides ultimately into free amino acids. These amino acids are more hydrophilic than peptides and therefore, the hydrophobicity decreased after digestion with trypsin.

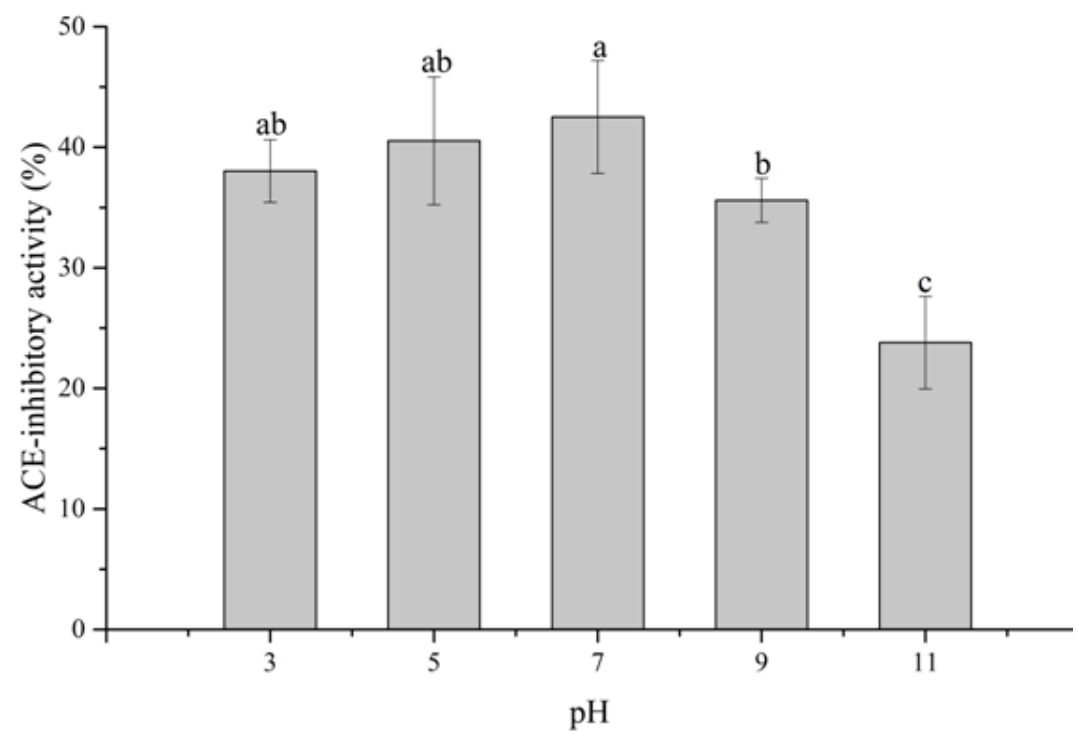

Figure 4. Changes in ACE-inhibitory activity of JHP at different $\mathrm{pH}$ values. Bars with different letters are significantly different 
Table 1. Total amino acid and free amino acid contents of JHP after simulated pepsin and trypsin digestion

\begin{tabular}{|c|c|c|c|c|}
\hline Amino acid & $\begin{array}{c}\text { Total amino acids } \\
(\mathrm{mg} / \mathrm{mL})\end{array}$ & $\begin{array}{c}\text { Free amino acids } \\
(\mathrm{mg} / \mathrm{mL})\end{array}$ & $\begin{array}{c}\text { Free amino acids after pepsin } \\
\text { digestion }(\mathrm{mg} / \mathrm{mL})\end{array}$ & $\begin{array}{c}\text { Free amino acids after trypsin } \\
\text { digestion }(\mathrm{mg} / \mathrm{mL})\end{array}$ \\
\hline Asp & $1.817 \pm 0.014$ & $0.367 \pm 0.019^{\mathrm{b}}$ & $0.376 \pm 0.010^{b}$ & $0.432 \pm 0.024^{\mathrm{a}}$ \\
\hline Glu & $4.664 \pm 0.071$ & $1.383 \pm 0.016^{\mathrm{b}}$ & $1.429 \pm 0.040^{\mathrm{b}}$ & $1.515 \pm 0.065^{\mathrm{a}}$ \\
\hline His & $4.146 \pm 0.071$ & $1.319 \pm 0.062^{\mathrm{a}}$ & $1.330 \pm 0.046^{\mathrm{a}}$ & $1.356 \pm 0.014^{\mathrm{a}}$ \\
\hline Gly & $1.120 \pm 0.018$ & $0.284 \pm 0.013^{b}$ & $0.291 \pm 0.008^{b}$ & $0.362 \pm 0.027^{\mathrm{a}}$ \\
\hline Thr & $1.752 \pm 0.020$ & $0.499 \pm 0.038^{b}$ & $0.520 \pm 0.029^{b}$ & $0.635 \pm 0.010^{\mathrm{a}}$ \\
\hline Cys & $0.102 \pm 0.004$ & $0.048 \pm 0.005^{\mathrm{ab}}$ & $0.049 \pm 0.004^{\mathrm{a}}$ & $0.042 \pm 0.007^{\mathrm{b}}$ \\
\hline Met & $0.429 \pm 0.018$ & $0.229 \pm 0.010^{\mathrm{a}}$ & $0.233 \pm 0.004^{\mathrm{a}}$ & $0.238 \pm 0.038^{\mathrm{a}}$ \\
\hline Lys & $2.626 \pm 0.034$ & $0.869 \pm 0.028^{b}$ & $0.873 \pm 0.039^{b}$ & $0.948 \pm 0.027^{\mathrm{a}}$ \\
\hline Ser & $0.603 \pm 0.005$ & $0.129 \pm 0.008^{\mathrm{a}}$ & $0.134 \pm 0.004^{\mathrm{a}}$ & $0.136 \pm 0.004^{\mathrm{a}}$ \\
\hline Arg & $0.852 \pm 0.029$ & $0.238 \pm 0.022^{\mathrm{b}}$ & $0.240 \pm 0.011^{\mathrm{b}}$ & $0.267 \pm 0.021^{\mathrm{a}}$ \\
\hline Ala & $2.032 \pm 0.035$ & $0.657 \pm 0.011^{\mathrm{c}}$ & $0.753 \pm 0.017^{\mathrm{b}}$ & $0.959 \pm 0.013^{\mathrm{a}}$ \\
\hline Tyr & $0.594 \pm 0.018$ & $0.246 \pm 0.004^{\mathrm{c}}$ & $0.261 \pm 0.008^{b}$ & $0.299 \pm 0.021^{\mathrm{a}}$ \\
\hline Val & $1.993 \pm 0.030$ & $0.737 \pm 0.024^{\mathrm{c}}$ & $0.769 \pm 0.018^{b}$ & $0.893 \pm 0.011^{\mathrm{a}}$ \\
\hline Phe & $1.033 \pm 0.021$ & $0.356 \pm 0.056^{\mathrm{b}}$ & $0.377 \pm 0.048^{b}$ & $0.485 \pm 0.016^{\mathrm{a}}$ \\
\hline Ile & $1.438 \pm 0.041$ & $0.588 \pm 0.020^{\mathrm{b}}$ & $0.620 \pm 0.017^{b}$ & $0.672 \pm 0.031^{\mathrm{a}}$ \\
\hline Leu & $1.928 \pm 0.032$ & $0.765 \pm 0.032^{\mathrm{c}}$ & $0.808 \pm 0.013^{\mathrm{b}}$ & $0.884 \pm 0.023^{\mathrm{a}}$ \\
\hline Pro & $0.561 \pm 0.044$ & $0.191 \pm 0.010^{\mathrm{b}}$ & $0.195 \pm 0.002^{b}$ & $0.216 \pm 0.034^{\mathrm{a}}$ \\
\hline Total & $27.669 \pm 0.367$ & $8.907 \pm 0.312^{\mathrm{b}}$ & $9.259 \pm 0.233^{b}$ & $10.335 \pm 0.235^{\mathrm{a}}$ \\
\hline $\begin{array}{l}\text { Free amino acids } \\
\text { percentage }(\%)\end{array}$ & & 32.19 & 33.46 & 37.35 \\
\hline
\end{tabular}

Mean values \pm standard deviations $(\mathrm{n}=6)$. Different letters are used to show significant differences $(\mathrm{P}<0.05)$.

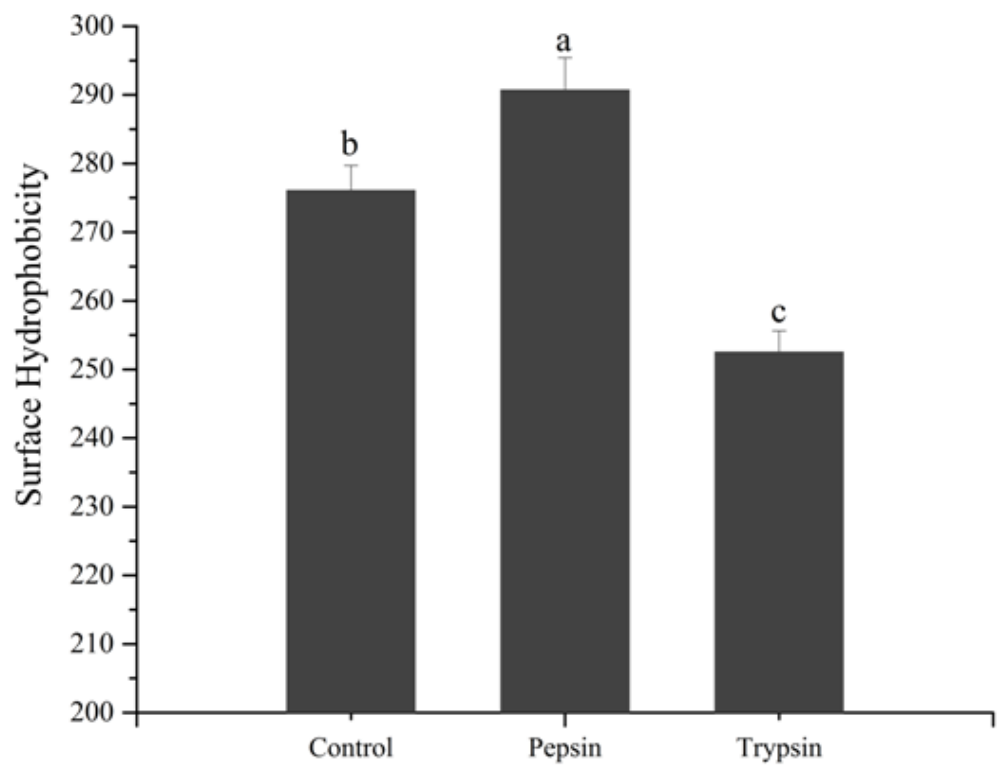

Simulated gastro-intestinal digestion

Figure 5. Changes in surface hydrophobicity of JHP following pepsin-trypsin simulated digestion. Bars with different letters are significantly different

Table 2. ACE-inhibitory activity of JHP before and after pepsin-trypsin simulated digestion

\begin{tabular}{lc}
\hline Samples & ACE-inhibitory activity (\%) \\
\hline Peptides & $38.34 \pm 1.43^{\mathrm{b}}$ \\
Peptides + pepsin & $42.34 \pm 1.58^{\mathrm{a}}$ \\
Peptides + pepsin + trypsin & $43.12 \pm 2.11^{\mathrm{a}}$ \\
\hline
\end{tabular}

Mean values \pm standard deviations $(n=6)$. Different letters are used to show significant differences $(\mathrm{P}<0.05)$.

\subsection{Effect of in vitro digestion on ACE- inhibitory activity of JHP}

Compared to the control sample, the ACE-inhibitory activity of JHP increased when subjected to in vitro digestion with pepsin and trypsin (Table 2). However, no significant differences were observed between the two steps of the in vitro digestion.

New antihypertensive peptides could be released by the treatment with pepsin. It has been reported that ACE inhibiting 
peptides such as KRQKYD and EKERERQ have been identified following the hydrolysis of porcine muscle with pepsin [35]. Muguruma, Ahhmed [36] isolated a novel peptide sequenced (KRVITY) from porcine skeletal myosin using pepsin treatment. In addition, as mentioned above, hydrophobic residues at the C-terminal of peptides contribute to their ACE-inhibitory potency. Following the treatment with pepsin, the exposure of hydrophobic groups contributed to the increased ACE-inhibitory activity. In this study, the ACE-inhibitory activity of samples was significantly increased by in vitro digestion with pepsin. This could be a consequence of the generation of new peptides with an ACE-inhibitory activity with the greater exposure of hydrophobic residues after pepsin treatment.

In a study with pea and whey proteins, Vermeirssen, Van Camp [37] reported that in a simulated gastro-intestinal digestion, the extent of proteolysis was the predominant factor controlling ACE-inhibitory activity. A number of peptides were degraded by digestive enzymes, forming new bioactive peptides during simulated digestion. Also, some bioactive peptides may be hydrolyzed leading to the loss of their bioactivity. In this study, the changes of ACE-inhibitory activity of JHP after in vitro digestion could result from the generation of new ACE-inhibitory peptides and the degradation of original ACE-inhibitory peptides. In term of degradation of the original peptides, it has been postulated that C-terminal proline, or hydrophobic residues, are somewhat resistant to the degradation by digestive enzymes [38]. Thus, the increase of ACE-inhibitory activity in our research probably resulted from the generation of bioactive peptides after pepsin treatment. Due to a balance between the generation and the degradation of ACE-inhibitory peptides, no significant differences between pepsin and trypsin treatment were to be found.

\section{Conclusion}

According to the current study, ACE-inhibitory peptides were stable against heat treatment as well as the $\mathrm{NaCl}$. Alkaline conditions were unfavorable for the stability of ACE-inhibitory peptides, while under acid conditions their bioactivity was not different from that at $\mathrm{pH}$ 7.0. JHP proved to be a good source of ACE-inhibitory activity after pepsin and trypsin simulated gastro-intestinal digestion, where the activity was increased compared to samples before digestion. However, there was no significant difference between the two steps of the digestion. These changes may be due to the interaction between the generation of new ACE-inhibitory peptides and the degradation of original ACE-inhibitory peptides. The results indicate that pepsin hydrolyzed peptides into smaller units leading to the exposure of more hydrophobic residues which were favorable for the ACE-inhibitory activity, whereas trypsin released more free amino acids whilst catalyzing proteolysis.

\section{Acknowledgements}

This study was supported by the Thirteenth Five Issues of Rural Areas of People's Republic of China (2016YFD0401502; 2016YFD0400703).

\section{References}

[1] Möller, N. P., Scholzahrens, K. E., Roos, N. and Schrezenmeir, J. Bioactive peptides and proteins from foods: indication for health effects. European Journal of Nutrition, 47 (4), 171-182. 2008.

[2] Erdmann, K., Cheung, B. W. Y. and Schröder, H. The possible roles of food-derived bioactive peptides in reducing the risk of cardiovascular disease. Journal of Nutritional Biochemistry, 19 (10), 643-54. 2008.

[3] Himali, S., Zhang, W. G., Lee, E. J. and Ahn, D. U. Egg Yolk Phosvitin and Functional Phosphopeptides-Review. Journal of Food Science, 76 (7), R143-R150. 2011.

[4] Di, B. R., Harnedy, P., Bolton, D., Kerry, J., O'Neill, E., Mullen, A. M. and Hayes, M. Antioxidant and antimicrobial peptidic hydrolysates from muscle protein sources and by-products. Food Chemistry, 124 (4), 1296-1307. 2011.

[5] Zhang, W., Xiao, S., Himali, S., Lee, E. J. and Ahn, D. U. Improving functional value of meat products. Meat Science, 86 (1) 15-31. 2010.

[6] Vermeirssen, V., Deplancke, B., Tappenden, K. A., Van, C. J., Gaskins, H. R. and Verstraete, W. Intestinal transport of the lactokinin Ala-Leu-Pro-Met-His-Ile-Arg through a Caco-2 Bbe Monolayer. Journal of Peptide Science An Official Publication of the European Peptide Society, 8 (3), 95-100. 2002.

[7] Leggio, A., Belsito, E. L., Marco, R. D., Di Gioia, M. L., Liguori, A., Siciliano, C. and Spinella, M. Dry fermented sausages of Southern Italy: a comparison of free amino acids and biogenic amines between industrial and homemade products. Journal of Food Science, 77(4), S170-S175. 2012.

[8] Zhou, G. and Zhao, G. Biochemical changes during processing of traditional Jinhua ham. Meat Science, 77 (1), 114-120. 2007.

[9] Zhang, J., Zhen, Z., Zhang, W., Zeng, T. and Zhou, G. Effect of intensifying high-temperature ripening on proteolysis, lipolysis and flavor of Jinhua ham. Journal of the Science of Food and Agriculture, 89 (5), 834-842. 2009.

[10] Hu, Y. Y., Xing, L. J., Zhou, G. H. and Zhang, W. G. Antioxidant activity of crude peptides extracted from dry-cured Jinhua ham. Journal of Food and Nutrition Research, 19(9), 629-640. 2016.

[11] Liu, R., Xing, L., Fu, Q., Zhou, G. H. and Zhang, W. G. A Review of Antioxidant Peptides Derived from Meat Muscle and ByProducts. Antioxidants, 5(3), E32. 2016.

[12] Zhu, C. Z., Zhang, W. G., Zhou, G. H., Xu, X. L., Kang, Z. L. and Yin, Y. Isolation and identification of antioxidant peptides from Jinhua ham. Journal of Agricultural and Food Chemistry, 61 (6), 1265-1271. 2013.

[13] Jr, S. L., Kahn, J. R. and Shumway, N. P. The preparation and function of the hypertensin-converting enzyme. Journal of Experimental Medicine, 103 (3), 295-299. 1956.

[14] Matsui, T. and Tanaka, M. Antihypertensive Peptides and Their Underlying Mechanisms. Wiley-Blackwell, 2010, 43-54.

[15] Ferreira, S. H., Bartelt, D. C. and Greene, L. J. Isolation of bradykinin-potentiating peptides from Bothrops jararaca venom. Biochemistry, 9 (13), 2583-93. 1970.

[16] Escudero, E., Sentandreu, M. A., Arihara, K. and Toldrá, F. Angiotensin I-converting enzyme inhibitory peptides generated from in vitro gastrointestinal digestion of pork meat. Journal of Agricultural \& Food Chemistry, 58(5), 2895-2901. 2010.

[17] Escudero, E., Aristoy, M. C., Nishimura, H., Arihara, K. and Toldrá, F. Antihypertensive effect and antioxidant activity of peptide fractions extracted from Spanish dry-cured ham. Meat Science, 91 (3), 306-311. 2012.

[18] Xing, L. J., Hu, Y. Y., Hu, H. Y., Ge, Q. F., Zhou, G. H. and Zhang, W. G. Purification and identification of antioxidative peptides from dry-cured Xuanwei ham. Food chemistry, 194, 951-958. 2016.

[19] Church, F. C., Swaisgood, H. E., Porter, D. H. and Catignani, G. L. Spectrophotometric assay using o-phthaldialdehyde for determination of proteolysis in milk and isolated milk proteins. Journal of Dairy Science, 66 (6), 1219-1227. 1983.

[20] Cushman, D. W. and Cheung, H. S. Spectrophotometric assay and properties of the angiotensin-converting enzyme of rabbit lung. Biochemical Pharmacology, 20 (7), 1637. 1971.

[21] De, B. P., Deplancke, B. and Verstraete, W. Fermentation by gut microbiota cultured in a simulator of the human intestinal microbial ecosystem is improved by supplementing a soygerm powder. Journal of Nutrition, 130 (10), 2599-2606. 2000. 
[22] Bidlingmeyer, B. A., Cohen, S. A., Tarvin, T. L. and Frost, B. A new, rapid, high-sensitivity analysis of amino acids in food type samples. Journal - Association of Official Analytical Chemists, 70 (2), 241-247. 1987.

[23] Juanmarcos, A. A., Purevdorj, N. O., Kayoko, T., Kenichiro, S., Michihiro, F. and Mitsuo, S. The effect of starter cultures on proteolytic changes and amino acid content in fermented sausages. Food Chemistry, 119 (1), 279-285. 2010.

[24] Haskard, C. A. and Ecy, L. C. Hydrophobicity of bovine serum albumin and ovalbumin determined using uncharged (PRODAN) and anionic (ANS-) fluorescent probes. Journal of Agricultural \& Food Chemistry, 46 (7), 2671-2677. 1998.

[25] Zhao, G., Tian, W., Liu, Y., Zhou, G., Xu, X. and Li, M. Proteolysis in biceps femoris during Jinhua ham processing. Meat Science, 79 (1), 39-45. 2008.

[26] Escudero, E., Mora, L. and Toldrá, F. Stability of ACE inhibitory ham peptides against heat treatment and in vitro digestion. Food Chemistry, 161 (5), 305. 2014.

[27] Hwang, J. S. Impact of processing on stability of angiotensin Iconverting enzyme (ACE) inhibitory peptides obtained from tuna cooking juice. Food Research International, 43 (3), 902-906. 2010.

[28] Zhu, C. Z., Zhang, W. G., Kang, Z. L., Zhou, G. H. and Xu, X. L. Stability of an antioxidant peptide extracted from Jinhua ham Meat Science, 96 (2), 783-789. 2014.

[29] Zhu, C. Z., Zhang, W. G., Zhou, G. H. and Xu, X. L. Identification of antioxidant peptides of Jinhua ham generated in the products and through the simulated gastrointestinal digestion system. Journal of the Science of Food and Agriculture, 96 (1), 99-108. 2016.

[30] Hou, F., Ding, W., Qu, W., Oladejo, A. O., Xiong, F., Zhang, W., $\mathrm{He}, \mathrm{R}$. and $\mathrm{Ma}, \mathrm{H}$. Alkali solution extraction of rice residue protein isolates: Influence of alkali concentration on protein functional, structural properties and lysinoalanine formation. Food Chemistry, 218, 207-215. 2016.

[31] Maebuchi, M., Samoto, M., Kohno, M., Ito, R., Koikeda, T., Hirotsuka, M. and Nakabou, Y. Improvement in the intestinal absorption of soy protein by enzymatic digestion to oligopeptide in healthy adult men. Food Science \& Technology Research, 13 (1), 45-53. 2007.

[32] Vermeirssen, V., Van, C. J. and Verstraete, W. Bioavailability of angiotensin I converting enzyme inhibitory peptides. British Journal of Nutrition, 92 (3), 357-366. 2004.

[33] Meisel, H. Biochemical properties of regulatory prptides derived from milk proteins. Biopolymers, 43 (2), 119-128. 1997.

[34] Pacifici, R. E., Kono, Y. and Davies, K. J., Hydrophobicity as the signal for selective degradation of hydroxyl radical-modified hemoglobin by the multicatalytic proteinase complex, proteasome. The Journal of Biological Chemistry, 268 (21), 15405-15411. 1993.

[35] Katayama, K., Anggraeni, H. E., Mori, T., Ahhmed, A. M., Kawahara, S., Sugiyama, M., Nakayama, T., Maruyama, M. and Muguruma, M. Porcine Skeletal Muscle Troponin Is a Good Source of Peptides with Angiotensin-I Converting Enzyme Inhibitory Activity and Antihypertensive Effects in Spontaneously Hypertensive Rats. Journal of Agricultural \& Food Chemistry, 56 (2), 355-360. 2008.

[36] Muguruma, M., Ahhmed, A. M., Katayama, K., Kawahara, S. Maruyama, M. and Nakamura, T. Identification of pro-drug type ACE inhibitory peptide sourced from porcine myosin B: Evaluation of its antihypertensive effects in vivo. Food Chemistry, 114 (2), 516-522. 2009.

[37] Vermeirssen, V., Van Camp, J., Decroos, K., Van Wijmelbeke, L. and Verstraete, W. The Impact of Fermentation and In Vitro Digestion on the Formation of ACE Inhibitory Activity from Pea and Whey Protein. Journal of Dairy Science, 86 (2), 429-438. 2003.

[38] Matsufuji, H., Matsui, T., Seki, E., Osajima, K., Nakashima, M. and Osajima, Y. Angiotensin I-converting Enzyme Inhibitory Peptides in an Alkaline Protease Hydrolyzate Derived from Sardine Muscle. Bioscience Biotechnology \& Biochemistry, 58 (12), 2244-2245. 1994. 